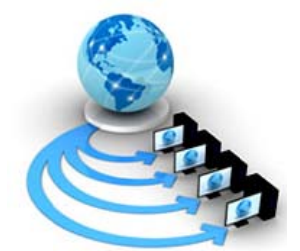

Volume 9, No. 2, March-April 2018

International Journal of Advanced Research in Computer Science

RESEARCH PAPER

Available Online at www.ijarcs.info

\title{
THE IDENTIFICATION OF RIGHT INFORMATION SYSTEM IN THE RETAIL SECTOR FIRM
}

\author{
Pooja Shrimali \\ Informatics \& Computational Sciences, \\ Mohanlal Sukhadia University, \\ Udaipur,(Raj.),India
}

\author{
Tarun Shrimali \\ ${ }^{2}$ Research and Development Cell, \\ JRN Rajasthan Vidyapeeth (Deemed to be University), \\ Udaipur,(Raj.),India
}

\author{
Chetan Mali \\ ${ }^{3}$ Informatics \& Computational Sciences, \\ Mohanlal Sukhadia University, \\ Udaipur,(Raj.),India
}

\begin{abstract}
Business information is a crucial asset for the management in a retail organization which cooperates in decision making, operational executions, and technological advancement etc. The Information is required to be processed through database so the selection and identification of right Information System are required as per the nature of the retail organization. There are various types of Information System (IS) as Customer Relationship Management System, Management Information System, Enterprises Resource Planning, Decision Support Systems, corporate website etc. It is studied in this report that which type of IS fits in a large sized organization in the retail sector. The analysis of each IS explored representing the significance, applications, and implication into the selected criteria. It is observed that each IS has some specialty which meets the exact requirements of business in different segments. Moreover, the justified identification of IS understood through research study and analysis. The identification of right IS selection is well processed under a proper research design which concludes effective outcomes for the research objectives.
\end{abstract}

Keywords: Retail Industry, Information System (IS), Customer Relationship Management (CRM), Enterprise Resource Planning (ERP), Decision Support Systems (DSS), Selecting Information System

\section{INTRODUCTION}

The information is a set of facts and figures about specific objective which is researched and studied from sources of collecting data and processing for retail business objectives. In the large retail organizations, the business requires multiple resources for the development of customer base, human resource functions or any other operations. It is discussed that various functional operations and business practices are managed through accessing system database which depends on information. In spite of the involvement of different tools and technologies of information technology, it is discussed in the research that using knowledge resources and software applications for serving business stakeholders. The accomplishing of business objectives using Information system into a large sized retail organization is observed through the right selection out of MIS, CRM, ERP and DSS which is identified through accessing parameters for the operational process requirements (Almajali, Masa'deh \& Tarhini, 2016) ${ }^{[1]}$. The discussion is done through the evaluation of these types of Information Systems in context to the retail organization; the findings and analysis are representing suitable solutions.

\section{AIM OF THE STUDY}

The review of Information Technology (IT) needs of the retail business are for maximizing business profit, improving sales as well as managing a range of products, inventory and production management. It is aimed to find the right IS for the large retail organization considering the global and national scenario of this business industry (Amoako, Adjaison, Kumi \& Asamoah, 2015) ${ }^{[2]}$.

\section{REVIEW OF LITERATURE Needs of IS the retail organization}

According to the research analysis and findings of (Beck, 2018) [3], a retail business is managed through different operations and practices which are associated with functional practices. It is observed that various functional departments like human resource, finance and accounts, supply chain and marketing, operations and productions management etc. are identified as key functional units in business. It is found that the involvement of research and development from employees help in collecting information about products and customers is gathered into management information databases. Moreover, it is understood that the development of the functional area in retailing services as well as the management of useful information regarding product and service delivery is managed through the available information.

As per the research study of (George, 2015) ${ }^{[4]}$, the role of customer and other stakeholders for attaining business perspectives, it has become necessary to use information technology as well as other engineering tools for business in retails. The role of understanding information resources in retailing business services is the main functional area as marketing, sales, human resource and finance which will affect demands of customers and serviceability by the employees and management. It is 
noticed that various retail operations need monitoring and control support from the information system. It is found necessary to evaluate a system for information collection and processing for the employee's scheduled jobs. For example, the information about the performance of existing employees and new candidates is searched from human resource department database to manage the workforce.

\section{Available types of Information Systems for the retail sector}

According to the research study of (Kurnia, Choudrie, Mahbubur \& Alzougool, 2015) ${ }^{[5]}$, the training and development requirements of employees, as well as the data and facts, are collected for their performance in business operations. There are various functional operations in human resource development like recruitment, selection, hiring and agreements for engaging employees in retailing business services. The different candidate profiles like academic and work experience details are stored in form of professional and personal work experience. The involvement of tools and technologies like management information system (MIS), it is observed that human resource programs are organized on the basis of information which is collected from knowledge resources like job websites and portals. Moreover, the other management decisions are supported by the information available in system databases.

As per the research study of (Drucker, 2017) ${ }^{[6]}$, there are multiple business information systems which help different functional departments in retailing operations. Through effective use of information system, it is observed that certain changes can be accomplished through accessing and saving information in databases of organizations. There are various information systems like management information system (MIS), Decision Support System (DSS), Executive Support System (ESS), Customer relationship management system (CRM), Enterprises resource planning system (ERP) etc. which helps to manage various operational practices and services for business like retailing, pharmaceutical, agriculture etc. business sectors. Through the involvement of operations and services in retail business practices, the effective use of information access through such system is genuine for the large business firms.

\section{Trends and practices of IT addressing issues of retail organization}

As per the research was done by (Ivanov \& Mayorova, 2015) ${ }^{[7]}$, the business world is growing with information system capabilities and potential to serve functional units. It is observed that with improvements and development in information technology has influenced the different services and products of retail business organizations which are introduced after proper market research and development and genuine operational strategy regarding manufacturing and selling. To develop and create the global market for a successful and growing business firm, the products and services are required to be promoted on a large scale. The monitoring and control of functional units through the information system is accessed for strategizing globalization in business.
According to the research study undertaken by (Morgan, Richey Jr \& Autry, 2016) ${ }^{[8]}$, there are multiple opportunities in the retail business while information technology and other engineering resources are accessed for planning and implication of retail functions. It is understood that improvement of strategies for business in the global market, the data and records are collected from various resources as online references, books, journals, past records in business, competitor planning information, marketing, and sales survey etc. The changing demand of customers in the retail market, the business firm are planning to expand their business with effective information in information systems. It is understood that having operational excellence in their businesses, the firms are accessing information system like MIS and ERP. The large range of retail products and services in the business offering, the demand of customer and employees has been increasing to get better control of the overall supply chain functions.

\section{Application of various IS in the retail sector}

As per the research study of (Laudon \& Laudon, 2016) ${ }^{[9]}$, the fulfilment of consumer's demand, MIS is having features of gathering information and transferring to its authenticated user for business welfare. The improved decision making is the demand of business firm due to the criticality of services and delivery of quality products required to be managed in getting competitive advantages. The effective and efficient information system accesses multiple resources of business which can be managed for different retail functions to create some values. Moreover, the researched and processed information is qualified and quantified for getting rights decision in production and operations. So it is found that different tools and technologies of IT as application software for IS, websites, social media etc. are accessed to collect useful information. For obtaining the desired objectives in business, a retail IS support employees and management to deliver expected products and services to customers.

As per the research was undertaken by (Almajali, Masa'deh \& Tarhini, 2016) ${ }^{[1]}$ defines that giant business at the global level has multiple functional and operational practices. The retailing business is found that rapidly growing because of the changing customer perception towards the high level of market competition and inconsistency. It is noticed that certain values of the business are changing on day to day basis which needs to track market conditions and globalization adequately and quickly. So the robust technological system is required to handle information management in the retail operations. The involvement of management information system addresses the range of services in retail stored and their controls through the centralized locations. The development of products and services for customers is managed through the effective use of IT and engineering tools while developing IS software systems like CRM, MIS, and ERP etc.

\section{SAMPLE DESCRIPTION}

It is well known that a sample discloses the criteria of a research study which support in evaluation and analysis of the undertaken objectives. Here, the sample of findings results for the identified problems, objectives, scope, participants of the research study. The problem identified in this research is finding the right IS solution for the large 
sized retail organization which can address all the necessary resources required in applications. It is considered that the sample is focusing the aim of finding information through parameters of defines objectives and scope of the research. The scope of research is considering the global as well as the national platform for retail industry (Sharma \& Shah, 2015) ${ }^{[10]}$. Moreover, the facts and findings of research will define the target audience which is employees, managers, customers and IT team for the purpose of getting right IS in the target segment. The significance of the study is the learning and knowledge conceded for identifying right IS in retail sector organization to meet organizational mission and vision. The sampling will be census so the research study will be able to include vast feedback which can derive proper results. It is considered that qualitative analysis with census sampling is undertaken which will analyze the studied literature reviews learning with feedback from participants to draw the results.

\section{SIGNIFICANCE OF THE STUDY}

The undertaken research will be useful for learning the different types of IS and their applicability to the large-sized retail firm. Moreover, it will help readers in attaining knowledge about practices for selecting right IS for the retail sector (Ngai, Peng, Alexander \& Moon, 2014) ${ }^{[11]}$. Further, the study will help other researchers and scholars in initiating relevant research over are usage in retail business.

\section{DATA COLLECTION METHOD}

The undertaken research study is considering census sampling hence including all possible employees, managers and IT team members of a large sized retail organization. It is having interviews through individual interaction regarding the functional correlation with the information system (Wildemuth, 2016) ${ }^{\text {[12] }}$. It will be considering the requirement of participants with the IS in their organization alongside the idle reviews for making effective use of IS. Along with this, the collected secondary research will be analyzed and discussed with these participants so that they can have the better understanding of the purpose while giving their reviews.

\section{DATA ANALYSIS METHODS}

It is considered for the undertaken research study that the retail organizations are having a good number of employees in all the functional departments and it will focus on associating secondary research with the reviews of participants. It will be a qualitative analysis of the facts and findings of this research. So the study will focus on making secondary research study as a base for research and further consider the reviews of participants (Silverman, 2016) ${ }^{[13]}$. It will be including the contextual study analysis which considers the secondary research findings and applicability to the retail sector.

\section{FINDINGS}

Through the research and development of knowledge and learning made through the undertaken data collected through participants on the basis of literature reviews, the report has some findings over decided parameters (Jóczik \& Sasvári, 2014) ${ }^{[14]}$. It is observed that the literature reviews have been considering all the types of IS to learn and identify the right choice for implementing into the retail organization. Moreover, the finding of the study is discussed ahead alongside the interview feedbacks. Here, the findings are interpreted as researched and studied during the learning through literature reviews and interviews of participants.

- The retail sector is having the large number of product range as well as employees and managers which need a heuristic IS to store personal, professional and business operations details (Sasvari \& Rauch, 2014) ${ }^{[15]}$.

- The retail business functions are including the inventory, sales, and procurement management in a glance which requires a systemized transportations, logistics, suppliers, employees and customer management (Kumar, Gurunathan \& Reddy, 2016) [16]

- Further, the study has considered the global platform for the research as well as Indian market scenario for the selection of large-sized retail organizations. It is including the study of both platforms for retail businesses considering the consequences (Singh, 2017) ${ }^{[17]}$.

- The global scenario of retail is having the large network of customers, employees as well as operational functions in retail firms so it is deriving the outcomes that having individual departmental databases is not enough for such firms(Kumar, Gurunathan \& Reddy, 2016) ${ }^{[16]}$.

- In the Indian market also, most of the functional departments in the retail sector are included which defines that in the leading retail organizations, there are similar requirements of having suitable IS (Singh, 2017) ${ }^{[17]}$.

- MIS is effective enough to address management decision making and CRM is having customer related management systems (Amoako, Adjaison, Kumi \& Asamoah, 2015) ${ }^{[2]}$. Although ERP has both the options for management and customer relationship management it is able to efficiently manage other functional databases like warehousing, HR, IT, sales etc.

- $\quad$ ERP is found most suitable with the flexibility for managing multiple functional database software and application system together so that all the retail functions can be managed on the larger scale (Sasvari \& Rauch, 2014) ${ }^{[15]}$.

- The interviewed participants having the similar thoughts while asked for the selection of MIS, CRM, DSS and ERP system applicability in their organizations. It is found that most of the participants have selected ERP as their necessary IS in their business (Garg \& Khurana, 2017) ${ }^{[18]}$.

- The $80 \%$ of the total 70 management employees have been reviewed ERP as their first choice while $90 \%$ of operational employees have suggested it. Even the IT team members have $85 \%$ votes for ERP system to be accessed in the large-scale retail organization (Becker, Clever, Holler \& Neumann, 2018) ${ }^{[19]}$.

These findings are crucial for the learning and understanding of retail organization functions and succeeded need of compatible IS in the firms. 


\section{DISCUSSION}

Here, all the types of IS are discussed here which can help in attaining the understanding of results more effectively. It will also justify the selection of ERP over other types of IS.

- MIS: Using MIS, the management of a business can handle routine and rotational situations in business through the involvement of databases and input-process-output model and other technologies. The involvements of multiple practices which are associated with human resources, financial management, marketing etc. are supported through MIS (Amoako, Adjaison, Kumi \& Asamoah, 2015) [2].

- DSS: DSS is also a management decision-making system which provides details about products and services of a retailing business. The critical situations of business and different functional areas are handled by respective managers through use of previous decisions made and stored in databases (Jóczik \& Sasvári, 2014) ${ }^{[14]}$. The access to electronic and information technology-based equipment help in maintaining DSS which makes the useful impact in taking solutions for problems and issues in operations of retailing in organizations. The decision making process acquires information from online and records of issues and respective solutions made. It is noticed that certain improvements in existing system can be managed through DSS with decision taken by professionals. Such decisions are enabled through database facts and figures about issues and problems.

- CRM: The customer relationship is a crucial factor for businesses which is responsible in taking crucial decisions for clients and other stakeholders. The issues of customers can be solved through direct interaction of employees and consumers in CRM system. It is containing details of various problems which are associated to issues which are identical from tools and technologies of information system (Sasvari \& Rauch, 2014) ${ }^{[15]}$. CRM includes various modes of transaction for data and records according to demand of customers. It is noticed that various changes can be implemented in CRM on the basis of change requirements and attainment of problem solution objectives in business. It acquires information about customers' reviews about products and supply help in form of information to resolve issues through online application. For example, the quality issues in retailing services are managed through CRM which offers solutions for all possible data to resolve reverse logistics process.

- ERP: There is another information system named as ERP which is a software application worked as tool for providing online support to its authenticated users. All the business information and database files are managed through ERP system to provide details of management system (Ngai, Peng, Alexander \& Moon, 2014) ${ }^{[11]}$. This system connects different informational resources over a common platform to provide information regarding all the functional units, practices, business decisions etc. Through ERP, different information system can be accessed by business stakeholders with involvement of management and other executives. For example, the customers are interacted along with employees for resolving demand and supply problems and providing solutions for each issue individually.

\section{RECOMMENDATIONS}

- Through the research study of various IS, it is recommended to use a proper ERP system in the large sized retail organizations in India (Becker, Clever, Holler \& Neumann, 2018) ${ }^{[19]}$.

- It is suggested to evaluate the exact requirements of each organization and then select the IS which can be beneficial for costing, speed and flexibility of IS usage (Amoako, Adjaison, Kumi \& Asamoah, 2015) ${ }^{[2]}$.

- Moreover, there should be proper ERP installation and maintenance IT team who can manage all the system sustainably (Ngai, Peng, Alexander \& Moon, 2014) ${ }^{[11]}$.

\section{CONCLUSIONS}

It is found through the observation and study of research study of identifying right IS for large sized retail organization in Indian market that ERP system is more compatible in terms of fulfilling the overall information requirements. It is found that CRM, MIS, DSS has some specific features and facilities which address individual stakeholders but ERP can address all the stakeholders as well as functional system to meet information access goals for doing business. The outcomes are justified with the reviews of interviews and previously studied research journals, articles and case studies.

\section{REFERENCES}

[1] Almajali, D. A., Masa'deh, R. E., \& Tarhini, A. (2016). Antecedents of ERP systems implementation success: a study on Jordanian healthcare sector. Journal of Enterprise Information Management, 29(4), 549-565.

[2] Amoako, G. K., Adjaison, G. K., Kumi, D. K., \& Asamoah, F. K. (2015). Using MIS for Strategic Planning and Management Control in Tourism Industries. In New Business Opportunities in the Growing E-Tourism Industry (pp. 20-42). IGI Global.

[3] Beck, A. (2018). Moving beyond shrinkage: developing a definition and typology of total retail loss. Security Journal, 31(1), 93-110.

[4] George, W. R. (2015). Internal marketing for retailers: The junior executive employee. In Proceedings of the 1984 Academy of Marketing Science (AMS) Annual Conference(pp. 322-325). Springer, Cham.

[5] Kurnia, S., Choudrie, J., Mahbubur, R. M., \& Alzougool, B. (2015). E-commerce technology adoption: A Malaysian grocery SME retail sector study. Journal of Business Research, 68(9), 1906-1918.

[6] Drucker, P. F. (2017). The Theory of the Business (Harvard Business Review Classics). Harvard Business Press.

[7] Ivanov, G., \& Mayorova, E. (2015). Intangible assets and competitive advantage in retail: case study from Russia. Asian Social Science, 11(12), 38.),

[8] Morgan, T. R., Richey Jr, R. G., \& Autry, C. W. (2016). Developing a reverse logistics competency: The influence of collaboration and information technology. 
International Journal of Physical Distribution \& Logistics Management, 46(3), 293-315.

[9] Laudon, K. C., \& Laudon, J. P. (2016). Management information system. Pearson Education India.

[10] Sharma, S., \& Shah, B. (2015). Thinking cloud-enabled adept and agile supply chain for SMEs: a conceptual study. International Journal of Business Information Systems, 19(3), 342-365.

[11] Ngai, E. W. T., Peng, S., Alexander, P., \& Moon, K. K. (2014). Decision support and intelligent systems in the textile and apparel supply chain: An academic review of research articles. Expert Systems with Applications, 41(1), 81-91

[12] Wildemuth, B. M. (Ed.). (2016). Applications of social research methods to questions in information and library science. ABC-CLIO.

[13] Silverman, D. (Ed.). (2016). Qualitative research. Sage.

[14] Jóczik, A., \& Sasvári, P. (2014). Differences In The Use Of IT Infrastructure Among Business Enterprises Operating In The Visegrád Group Of Countries. In CEEeGov Days 2014, eGovernment: Driver or stumbling block for European integration? Proceedings of the CEEeGov Days, May 8-9, 2014, Budapest. Wien: Österreichische Computer-Gesellschaft.

[15] Sasvari, P., \& Rauch, W. (2014). Information Systems and Economic Value Added: A Comparative Illustration of Austria and Hungary.

[16] Kumar, R. S., Gurunathan, K. B., \& Reddy, G. V. K. (2016). GROWTH AND PROSPECTS OF PRIVATE LABEL BRANDS IN INDIAN RETAIL INDUSTRY. Vidwat, 9(1), 4.

[17] Singh, A. P. (2017). Retail Market and FDI in Indian Scenario. Journal of Commerce, Economics \& Management, 1(2), 14-20.

[18] Garg, P., \& Khurana, R. (2017). Applying structural equation model to study the critical risks in ERP implementation in Indian retail. Benchmarking: An International Journal, 24(1), 143-162.

[19] Becker, J., Clever, N., Holler, J., \& Neumann, M. (2018). Business process management in the manufacturing industry: ERP replacement and ISO 9001 recertification supported by the icebricks method. In Business Process Management Cases (pp. 413-429). Springer, Cham. 